\title{
ANALISIS REGRESI KUANTIL
}

\author{
SAIDAH, FERRA YANUAR, DODI DEVIANTO \\ Program Studi Magister Matematika, \\ Fakultas Matematika dan Ilmu Pengetahuan Alam, Universitas Andalas Padang, \\ Kampus UNAND Limau Manis Padang, Indonesia \\ email : saidahalhabsy@gmail.com
}

\begin{abstract}
Abstrak. Regresi kuantil dapat digunakan untuk mengatasi keterbatasan regresi linear dalam menganalisis asumsi yang tidak terpenuhi pada regresi klasik, yaitu varians error bersifat tidak konstan disebut dengan masalah heteroskedastisitas. Salah satu cara mendeteksi masalah heteroskedastisitas adalah dengan uji Breusch Bagan Godfrey (BPG). Data yang akan digunakan pada penelitian ini adalah data sekunder. Untuk pengukuran kecocokan model yang dihasilkan dilakukan dengan menggunakan koefisien determinasi $R^{2}$ pada masing-masing kuantil. Dari analisis yang dilakukan diperoleh bahwa metode kuantil dapat mengatasi masalah heteroskedastisitas. Model dugaan yang diperoleh untuk setiap kuantil menghasilkan nilai koefisien determinasi $\left(R^{2}\right)$ yang cukup besar yaitu lebih dari $90 \%$. Hal ini mengindikasikan bahwa estimator dengan metode kuantil menghasilkan model yang baik.
\end{abstract}

Kata Kunci: Heteroskedastisitas, regresi kuantil

\section{Pendahuluan}

Analisis regresi adalah metode statistika yang paling sering digunakan dalam segala bidang ilmu pengetahuan, analisis ini bertujuan untuk memodelkan hubungan antara dua variabel yang terdiri dari variabel tak bebas $(Y)$ dengan satu atau lebih variabel bebas $(X)$ dalam suatu sistem. Hubungan antara variabel-variabel tersebut biasanya dinyatakan dalam suatu model regresi yang secara umum dinyatakan sebagai $Y=f(x)+\varepsilon, \varepsilon$ adalah komponen galat, model tersebut menghubungkan variabel bebas dan variabel tak bebas melalui suatu parameter yang dinamakan sebagai parameter regresi dinotasikan dengan $\beta$. Untuk mendapatkan model regresi dapat diperoleh dengan melakukan estimasi terhadap parameter modelnya.

Ada beberapa metode yang digunakan untuk estimasi parameter dalam persamaan regresi, salah satunya yang paling sering digunakan pada regresi klasik adalah metode kuadrat terkecil (MKT). Estimasi parameter dengan metode MKT yaitu dengan meminimumkan jumlah kuadrat error, dengan cara menurunkan jumlah kuadrat error terhadap masing-masing parameter regresi kemudian disamakan dengan nol. Pada regresi klasik suatu model yang baik memenuhi sifat Best Linear Unbiased Estimator (BLUE).

Pada Regresi klasik ada beberapa asumsi yang harus dipenuhi sehingga model bersifat BLUE, salah satu asumsi yang harus dipenuhi adalah homoskedastisitas (homoscedastycity). Homoskedastisitas merupakan nilai varian dari (error) bersifat konstan. Pelanggaran terhadap asumsi homoskedastisitas disebut dengan het- 
eroskedastisitas (heteroscedastycity). Pada saat melakukan estimasi dengan metode MKT kemudian terjadi heteroskedastisitas, maka model yang diperoleh tidak efisien dan tidak dapat dipercaya, akibatnya dapat menyesatkan kesimpulan yang diambil dari model regresi yang dibentuk. Untuk mendeteksi gejala heteroskedastisitas salah satunya menggunakan uji Breusch Pagan Godfrey (BPG).

Regresi kuantil merupakan suatu pendekatan dalam analisis regresi yang dikenalkan oleh Koenker dan Bassett (1978). Regresi kuantil dapat digunakan untuk mengatasi keterbatasan regresi linear dalam menganalisis asumsi yang tidak terpenuhi pada regresi klasik, yaitu error tidak berdistribusi normal, mudah terpengaruh oleh data pencilan dan varians error tidak konstan (heteroskedastisitas).

Pada penelitian ini diawali dengan tinjauan secara teoritis terhadap estimasi regresi klasik dan metode kuantil. Kemudian hasil kajian teoritis tersebut diterapkan pada suatu kelompok data aplikasi.

\section{Data dan Metode Penelitian}

Data yang akan digunakan pada penelitian ini adalah data sekunder yang diperoleh dari "Basic Econometrics" dengan jumlah pengamatan sebanyak 40. Pengolahan data pada penelitian ini menggunakan bantuan sofware $R$.

Pada penelitian ini merupakan regresi linier berganda terdiri dari satu variabel dependen $(Y)$ dan beberapa variabel independen $(X)$. Pada analisis regresi klasik, pendugaan parameter dilakukan dengan metode kuadrat terkecil prinsipnya meminimumkan jumlah kuadrat error. Jumlah kuadrat error secara matematis dapat dituliskan sebagai berikut:

$$
S=\sum_{i=1}^{n} e_{i}^{2}=\sum_{i=1}^{n}\left(Y_{i}-\beta_{0}-\beta_{1} X_{1 i}-\beta_{2} X_{2 i}\right)^{2}
$$

Dalam melakukan estimasi parameter dengan menggunakan metode MKT terdapat beberapa asumsi yang harus dipenuhi. Pada penelitian ini asumsi yang dilanggar adalah nilai varian error bersifar tidak konstan atau heteroskedastisitas. Untuk mendeteksi masalah heteroskedastisitas dilakukan dengan uji Breusch-Pagan Godfrey (BPG). Adapun statistic uji Breusch-Pagan sebagai berikut:

$$
B P=\frac{1}{2}\left(\sum_{i=1}^{n} x_{i} f_{i}\right)^{\prime}\left(\sum_{i=1}^{n} x_{i} x_{i}^{\prime}\right)\left(\sum_{i=1}^{n} x_{i} f_{i}\right)
$$

dengan $f_{i}=\left(\frac{\varepsilon_{i}^{2}}{\sigma^{2}}-1\right), \varepsilon_{i}=\left(y_{i}-\hat{y}_{i}\right)$ dan $\sigma^{2}=\sum_{i=1}^{n} \frac{\varepsilon_{i}^{2}}{n}$

Uji ini menyebar $\chi_{k-1}^{2}$, dimana $\mathrm{k}$ adalah banyaknya parameter regresi. Kriteria pengujiannya sebagai berikut:

$$
B P= \begin{cases}\leq \chi_{k-1}^{2}, \text { terima } & H_{0} \\ \geq \chi_{k-1}^{2}, \text { tolak } & H_{0}\end{cases}
$$

Salah satu metode untuk mengatasi masalah tersebut adalah metode regresi kuantil. Kuantil adalah suatu teknik pembagian sekelompok data kepada beberapa bagian yang sama, setelah data diurutkan dari yang paling kecil atau paling besar. Regresi kuantil merupakan suatu pendekatan dalam analisis regresi yang 
dikenalkan oleh Koenker dan Bassett. Model linier dari persamaan regresi kuantil dapat dituliskan sebagai:

$$
y_{i}=x_{i}^{\prime} \beta_{\theta}+\varepsilon_{i}
$$

Estimasi dengan metode regresi kuantil ke- $\theta$ diperoleh dengan meminimumkan jumlah nilai mutlak dari error dengan pembobot $\theta$ untuk error positif dan pembobot $(1-\theta)$ untuk error negatif yaitu:

$$
\min _{\beta \in R^{p}} \sum_{i=1}^{n} \rho_{p}\left(y_{i}-Q_{\theta}(Y \mid X)\right)
$$

dimana $p$ menyatakan indeks kuantil $\in(0,1), \rho_{p}$ merupakan loss function yang asimetrik, dimana $0<p<1$, dan $\rho_{p}(\varepsilon)$ merupakan Loss Function dari regresi kuantil yaitu:

$$
\rho_{p}(\varepsilon)=\left\{\begin{array}{cll}
p \varepsilon & , \text { jika } & \varepsilon \geq 0 \\
(p-1) \varepsilon, & \text { jika } & \varepsilon<0
\end{array}\right.
$$

\section{Hasil dan Pembahasan}

Analisis terhadap regresi klasik dengan metode MKT diberikan pada Gambar 1.

\begin{tabular}{|l|l|l|l|}
\hline & Koefisien & $\mathrm{p}$-value & Standar Error \\
\hline $\boldsymbol{\beta}_{\mathbf{0}}$ & 6.2737 & 0.542 & 10.1819 \\
\hline $\boldsymbol{\beta}_{\mathbf{1}}$ & $0.4874^{* *}$ & 0.0025 & 0.0136 \\
\hline $\boldsymbol{\beta}_{2}$ & $-7.8436^{* *}$ & 0.0035 & 1.2691 \\
\hline \multicolumn{4}{|c|}{ (**) Signifikan pada taraf $\alpha=0.05$}
\end{tabular}

Gambar 1. Hasil Estimasi Koefisien Dengan Metode MKT

Berdasarkan tabel pada Gambar 1 dapat diketahui bahwa estimasi koefisien regresi untuk $\beta_{1}$ dan $\beta_{2}$ signifikan pada taraf $\alpha=0.05$. Sedangkan estimasi koefisien regresi untuk $\beta_{0}$ tidak signifikan pada taraf $\alpha=0.05$.

Untuk mendeteksi masalah heteroskedastisitas digunakan uji Breusch-Pagan Godfrey (BPG) dengan bantuan sofware $R$. Hasil uji BPG diperoleh bahwa nilai $B P$ adalah 10.4858 sedangkan nilai $p$-value adalah 0.005285 , yaitu lebih kecil dari $\alpha=0.05$. Hal ini mengindikasikan terdapat masalah heteroskedastisitas artinya memiliki varians error yang tidak homogen.

Selanjutnya analisis terhadap metode regresi kuantil diberikan pada Gambar 2. Berdasarkan tabel pada Gambar 2 dapat diketahui bahwa estimasi koefisien regresi untuk $\beta_{1}$ dan $\beta_{2}$ signifikan pada taraf $\alpha=0.05$. Sedangkan estimasi koefisien regresi untuk $\beta_{0}$ tidak signifikan, yaitu pada kuantil ke-0.3, 0.4, 0.5, 0.6, 0.7, 0.8. Selanjutnya akan diuji apakah error dari model estimasi yang baru ini telah memiliki varians yang homogen atau tidak. Maka uji Breusch Pagan Godfrey (BPG) kembali dilakukan untuk mendeteksi masalah homogen. Berdasarkan uji BPG yang dilakukan, diperoleh hasil uji BPG tiap kuantil pada Gambar 3. 


\begin{tabular}{|l|l|l|l|l|l|l|l|l|}
\hline \multirow{2}{*}{$\begin{array}{l}\text { Kuantil } \\
(\mathbf{p})\end{array}$} & \multicolumn{9}{|c|}{ Koefisien Regresi } \\
\cline { 2 - 10 } & $\boldsymbol{\beta}_{\mathbf{0}}$ (Se) & p-value & \multicolumn{1}{|c|}{$\boldsymbol{\beta}_{\mathbf{1}}$ (Se) } & p-value & $\boldsymbol{\beta}_{2}$ (Se) & p-value \\
\hline 0.1 & $15.302^{* *}(2.453)$ & 0 & $0.431^{* *}(0.003)$ & 0 & $-6.274^{* *}(0.305)$ & 0 \\
\hline 0.2 & $4.351^{* *}(1.747)$ & 0.017 & $0.433^{* *}(0.002)$ & 0 & $-6.589^{* *}(0.218)$ & 0 \\
\hline 0.3 & 3.607 & $(2.254)$ & 0.118 & $0.432^{* *}(0.003)$ & 0 & $-6.329^{* *}(0.281)$ & 0 \\
\hline 0.4 & 5.009 & $(2.977)$ & 0.1 & $0.431^{* *}(0.003)$ & 0 & $-6.413^{* *}(0.371)$ & 0 \\
\hline 0.5 & 4.764 & $(5.878)$ & 0.422 & $0.445^{* *}(0.008)$ & 0 & $-6.543^{* *}(0.733)$ & 0 \\
\hline 0.6 & 0.536 & $(4.651)$ & 0.908 & $0.458^{* *}(0.007)$ & 0 & $-5.725^{* *}(0.579)$ & 0 \\
\hline 0.7 & 2.343 & $(5.286)$ & 0.66 & $0.468^{* *}(0.008)$ & 0 & $-6.114^{* *}(0.659)$ & 0 \\
\hline 0.8 & 3.884 & $(4.677)$ & 0.411 & $0.489^{* *}(0.007)$ & 0 & $-6.518^{* *}(0.583)$ & 0 \\
\hline 0.9 & $12.181^{* *}(5.311)$ & 0.027 & $0.518^{* *}(0.007)$ & 0 & $-7.511^{* *}(0.662)$ & 0 \\
\hline
\end{tabular}

Gambar 2. Hasil Estimasi Koefisien Regresi dengan Metode Kuantil

\begin{tabular}{|l|l|}
\hline Kuantil (p) & Uji BP (P-Value) \\
\hline 0.1 & $0.0597(0.807)$ \\
\hline 0.2 & $0.0721(0.7883)$ \\
\hline 0.3 & $0.0742(0.7853)$ \\
\hline 0.4 & $0.0502(0.8227)$ \\
\hline 0.5 & $0.1665(0.6832)$ \\
\hline 0.6 & $0.6977(0.4036)$ \\
\hline 0.7 & $3.5388(0.05995)$ \\
\hline 0.8 & $2.3705(0.1237)$ \\
\hline 0.9 & $0.0813(0.7756)$ \\
\hline
\end{tabular}

Gambar 3. Hasil Uji BPG Terhadap Heteroskedastisitas

Pada tabel pada Gambar 3 dapat dilihat uji BP tiap kuantil memiliki nilai $p$ - value lebih besar dari $\alpha=0.05$. Maka dapat disimpulkan bahwa varians error telah homogen, atau tidak ada masalah heteroskedastisitas lagi setelah penerapan metode kuantil. Selanjutnya mengukur kebaikan model pada tiap kuantil dengan menentukan nilai $R^{2}$.

Mengukur kecocokan model pada regresi linear berganda dapat menggunakan koefisien determinasi $R^{2}$. Hasil koefisien determinasi diperoleh pada tiap kuantil, dapat dilihat pada Gambar 4.

Dari tabel pada Gambar 4 dapat dilihat bahwa nilai $R^{2}$ untuk masing-masing kuantil lebih dari 0.90. Hal ini mengindikasikan bahwa semua model tiap kuantil sudah baik, yang mana peubah bebas yang digunakan dapat mempengaruhi peubah respon yaitu lebih dari $90 \%$. Nilai $R^{2}$ paling besar yaitu pada kuantil ke-0.70, dengan nilai sebesar 0.9677 . 


\begin{tabular}{|l|c|}
\hline Kuantil & $\mathbf{R}^{\mathbf{2}}$ \\
\hline 0.1 & 0.9596 \\
\hline 0.2 & 0.953 \\
\hline 0.3 & 0.954 \\
\hline 0.4 & 0.9539 \\
\hline 0.5 & 0.9586 \\
\hline 0.6 & 0.9676 \\
\hline 0.7 & 0.9677 \\
\hline 0.8 & 0.9624 \\
\hline 0.9 & 0.9382 \\
\hline
\end{tabular}

Gambar 4. Nilai $R^{2}$ Pada Metode Kuantil

\section{Kesimpulan}

Regresi kuantil dapat digunakan untuk mengatasi keterbatasan regresi linear dalam menganalisis asumsi yang tidak terpenuhi pada regresi klasik, yaitu varians error bersifat konstan (heteroskedastisitas). Dari analisis yang dilakukan diperoleh nilai $R^{2}$ masing-masing kuantil lebih dari $90 \%$, hal ini mengindikasikan bahwa estimator dengan metode kuantil sudah menghasilkan model estimasi yang baik.

\section{Daftar Pustaka}

[1] Arbia G. 2006. Spatial Econometrics: Statistical Foundation Application to Regional Convergence. Berlin: Springer

[2] Gujarati. 2008. Essentials Of Econometrics, 4th Edition, The McGraw-Hill Companies, New Jersey.

[3] Hoff, P.D., 2009, A First Course in Bayesian Statistical Methods, Springer, New York.

[4] Koenker, R. dan Basset, G.Jr. 1978. Regression Quantiles. Econometrica. 46 : $33-50$

[5] Kotz et al. 1998. An Asymmetric Multivariate Laplace Distribution. New York

[6] Koenker, R. dan K. Hallock. 2001. Quantile Regression. Journal of Economic Perspectives 15: 143 - 156

[7] Koenker, R. 2005. Quantile Regression. Cambridge University Press. New York.

[8] Walpole, R.E dan Myers, R.H. 1995. Ilmu Peluang dan Statistika untuk Insinyur dan Ilmuwan Edisi ke-4. Alih bahasa oleh Sembiring, R.K. ITB. Bandung 